\title{
Seed germination and development of desert rose seedlings (Adenium obesum Roem. \& Schult) on different substrates
}

\author{
Carolina Amorim Santos ${ }^{*}$ (D) Guilherme Amorim Homem de Abreu Loureiro ${ }^{2}$ (D) \\ Gedeon Almeida Gomes Júnior ${ }^{1}$ [D Rafaela Alves Pereira ${ }^{1}$ (i) George Andrade Sodré ${ }^{1}$ [i] \\ Rafael Marani Barbosa ${ }^{1}$ (D)
}

${ }^{1}$ Programa de Pós-graduação em Produção Vegetal, Universidade Estadual de Santa Cruz (UESC), 45662-900, Ilhéus, BA, Brasil. E-mail: calmorim@gmail.com. "Corresponding author.

${ }^{2}$ Universidad Autónoma del Estado de México, Toluca, Estado de México, México.

ABSTRACT: Desert rose (Adenium obesum) is a succulent plant that is native to the Arabian Peninsula. It has great commercial value with exuberant structure and flowering. It can be propagated by seeds to ensure maximum development of the caudex. Despite its high economic value, studies on its propagation are still required. The aim of this study was to evaluate seed germination performance and seedling development of desert rose seedlings in different substrates. Treatments comprised five different substrate compositions: S1 (Soil), S2 (Sand), S3 (Carolina Soil commercial substrate), S4 (Sand + Carolina Soil), and S5 (Soil+ Carolina Soil). The following were evaluated using uni- and multi-variate approaches: germination, first count, germination speed index, caudex diameter, number of leaves, seedling length, root length, shoot length, and fresh mass and dry mass. Sand is the ideal substrate for the germination of A. obesum seeds, while for forming seedlings, mixtures of the Carolina Soil commercial substrate with sand or soil should be used.

Key words: Apocynaceae, propagation, main components, ornamental plants.

Germinação de sementes e desenvolvimento de mudas de rosa do deserto (Adenium obesum Roem. \& Schult) em diferentes substratos

RESUMO: A rosa do deserto (Adenium obesum) é uma planta suculenta nativa da Península Arábica, apresenta grande valor comercial, com estrutura e floração exuberante. Sua propagação pode ser por meio de sementes para garantir o maior desenvolvimento do caudex. Apesar do alto valor econômico ainda se requerem estudos para sua propagação. O objetivo foi avaliar o desempenho germinativo de sementes e desenvolvimento de mudas de rosa-do-deserto em diferentes substratos. Os tratamentos constaram em cinco diferentes composições de substrato: S1 (Terra), S2 (Areia), S3 (substrato comercial Carolina Soil), S4 (Areia + Carolina Soil) e S5 (Terra + Carolina Soil). Foram avaliados com abordagem uni e multivariada: germinação, primeira contagem, indice de velocidade de germinação, diâmetro do caudex, número de folhas, comprimento da plântula, comprimento da raiz, comprimento da parte aérea, massa fresca e massa seca. A areia é o substrato ideal para a germinação de sementes de A. obesum, enquanto que para a formação das mudas deve-se utilizar as misturas do substrato comercial Carolina Soil com areia ou terra.

Palavras-chave: Apocynaceae, propagação, componentes principais, plantas ornamentais.

\section{INTRODUCTION}

The desert rose (Adenium obesum (Forssk.), Roem. \& Schult), belonging to the family Apocynaceae, is native to tropical Africa and Arabia but has been introduced and naturalized in different parts of the world (TALUKDAR, 2012; HOSSAIN, 2018). The species is extensively used in landscaping and interest has primarily increased because of its easy maintenance and tolerance to drought, as well as because of its variations in flower shapes and colors ranging from pink, red, white to yellow, as well as variegated specimens (HASTUTI et al., 2009; STEGANI et al., 2019). However, because of its high demand and the destruction of its natural habitat in certain tropical African countries, the desert rose is an endangered plant (TALUKDAR, 2012).

The slow-growing desert rose can be propagated by seeds and cuttings (ROMAHN, 2012). The plant has a thickened stem at the base called the 
caudex, an adaptation to store water and nutrients in arid places. Florists report that the thickening of the stem base can be shaped and thus attain higher market value; however, this characteristic is not manifested when the plant is vegetative propagated (STEGANI et al., 2019).

To ensure the propagation of a species; and consequently, its sustainable exploitation, knowledge of its seed germination process is essential, as well as the ideal substrates for the establishment and development of seedlings because the behavior of each species may differ in response to the same substrate (COLOMBO et al., 2017; GOMESJUNIOR et al., 2019).

Therefore, to provide physical and chemical support and ensure better seed germination and seedling development, the use of appropriate substrate is extremely important for producing these species on a large scale (COLOMBO et al., 2015, SODRÉ \& GOMES, 2019). Thus, the aim of this study was to evaluate the germination performance of $A$. obesum seeds and the potential for forming seedlings in different substrates.

\section{MATERIALS AND METHODS}

The study was developed in a greenhouse at the Cocoa Research Center [Centro de Pesquisas do Cacau - CEPEC] of the Executive Commission of the Cocoa Farming Plan [Comissão Executiva do Plano da Lavoura Cacaueira - CEPLAC], Ilhéus, Bahia, Brazil. Seeds of $A$. obesum were collected between April and June 2015, from stock plants with a mean age of five years in the CEPEC/CEPLAC germplasm collection. The experiment was conducted in completely randomized design. The treatments were S1, i.e., Soil; S2, i.e., Sand; S3, i.e., Carolina soil commercial substrate (peat moss and vermiculite); S4, i.e., soil + Carolina soil commercial substrate (1:1); and S5, i.e., Sand + Carolina soil commercial substrate (1:1).

In relation to physiological performance, the seeds of $A$. obesum were evaluated for germination (G), which was conducted with four replications of 25 seeds in styrofoam trays with cells filled with substrates (treatments), moistened with an amount of water equivalent to $60 \%$ of its retention capacity, and one seed per cell sown to a depth of $0.5 \mathrm{~cm}$. Trays were maintained in the greenhouse with natural lighting at a constant temperature of $25{ }^{\circ} \mathrm{C}$ and relative air humidity of $80 \%$. The evaluations were performed five and fourteen days after sowing, and the percentages of normal seedlings were calculated (BRASIL, 2009). The first germination count (FC) was performed together with the germination test by calculating the percentage of normal seedlings obtained on the fifth day after setting up the test. Germination speed index (GSI) was obtained by daily counts of the number of germinated seeds from the 5 th to the 14th days (MAGUIRE, 1962).

At 60 days after sowing, 15 sampling units were randomly selected to obtain the following variables: caudex diameter (CD), seedling length (SL), root length (RL), aerial part shoot length (APL). Measurements were taken using a digital caliper by measuring the central region of the caudex for the $\mathrm{CD}$; from the apex to the tip of the primary root of the seedling for the CL; from the collet to the end of the primary root for the RL; and from the apex to the collet of the seedling for the APL. Results are expressed in millimeters.

Then, the plants were separated into the shoot and root system and the following variables were determined: number of leaves (NL), which was the total leaf count; and fresh matter (FM) and dry matter (DM) of the seedlings. The FM of the seedlings was obtained after maintaining the samples in the greenhouse with forced air circulation at a temperature of $65{ }^{\circ} \mathrm{C}$ until they reached constant weight. Samples were weighed on an analytical balance with an accuracy of $0.001 \mathrm{~g}$.

Data were tested for normality and homoscedasticity, and then submitted to analysis of variance (ANOVA). The means were grouped by Scott-Knott procedure $(p<0.05)$. To better understand the relationships between the variables, multivariate exploratory technique of principal components was used.

\section{RESULTS}

According to the ANOVA, there was a significant effect for treatments (substrates) for germination $(\mathrm{G})$, first germination count (FC), and germination speed index (GSI) $(p<0.05)$. The desert rose seeds presented higher germination values for substrate S2 (63\%). The S3 treatment obtained the lowest values, thus providing less satisfactory results for the germination of desert rose seeds (Table 1). Results for first germination count (FC) and germination speed index (GSI) were higher than for the other treatments in S2, followed by S1 and S5, and they did not differ from each other and were higher than S4 and S3 (Table 1).

There was significance for all the seedling development variables $(p<0.05)$. The $\mathrm{CD}$ of the seedlings obtained in substrate S2 (sand) presented 
Table 1 - Germination (G), first germination count (FC), and germination speed index (GSI) of desert rose $(A$. obesum) seeds in different substrates.

\begin{tabular}{|c|c|c|c|}
\hline Treatament & G & $\mathrm{FC}$ & GSI \\
\hline & $\%$ & $\%$ & - \\
\hline S1 - Soil & $37 b^{1}$ & $33 \mathrm{~b}$ & $0.42 \mathrm{~b}$ \\
\hline S2 - Sand & $63 \mathrm{a}$ & $50 \mathrm{a}$ & $0.66 \mathrm{a}$ \\
\hline S3 - Carolina & $17 \mathrm{~d}$ & $13 \mathrm{~d}$ & $0.15 \mathrm{~d}$ \\
\hline S4 - Soil + Carolina & $27 \mathrm{c}$ & $23 \mathrm{c}$ & $0.30 \mathrm{c}$ \\
\hline S5 - Sand + Carolina & $37 \mathrm{~b}$ & $33 \mathrm{~b}$ & $0.42 \mathrm{~b}$ \\
\hline CV $(\%)$ & 12.8 & 15.3 & 13.2 \\
\hline
\end{tabular}

Means followed by the same letters do not differ from each other by the Scott-Knot test $(p<0.05)$.

higher values $(12.7 \mathrm{~mm})$ (Table 2$)$. In the data for seedling length (CL), the best results were for S3, followed by $\mathrm{S} 4$ and $\mathrm{S} 5$, which did not differ from each other and were higher than S1 and S2. The aerial part (APL) was higher than the others in S4 (42.1 $\mathrm{mm})$, followed by S5 $(39.3 \mathrm{~mm})$ and S3 $(37.9 \mathrm{~mm})$, which did not differ from each other and were higher than S1 (32.2 $\mathrm{mm})$ and S2 (26.1 mm) (Table 2). The root length (RL) was greater in the seedlings that developed in S3 $(67.3 \mathrm{~mm})$, followed by S2 $(60.3$ $\mathrm{mm}), \mathrm{S} 4(56.6 \mathrm{~mm})$ and $\mathrm{S} 5(55.6 \mathrm{~mm})$, which did not differ from each otherand were higher than $\mathrm{S} 1$ (Table 2). The number of leaves (NL) of the seedlings obtained in S3 and S5 did not differ from each other and were higher than in the other treatments. The highest means for FM and DM of the seedlings occurred in S4. For FM it was not higher than S3, and for MS it was higher than the other treatments. Poor performance of seedlings obtained in sand for both FM and DM is highlighted.
The variability of the data by principal component analysis (PCA) was 67.86\% explained in Principal Component 1 (PC1) and $21.05 \%$ in Principal Component 2 (PC2), resulting in $88.91 \%$ of the total data variability (Figure 1). The variables G, SL, GSI, APL, FM and DM were the ones that contributed most to $\mathrm{PC} 1$ formation. The variables related to germination performance (G, FC, and GSI) of desert rose seeds presented a negative correlation with PC1. The variables CD, RL, and SL contributed to the formation and presented a positive correlation with PC2 (Table 3).

\section{DISCUSSION}

The sand substrate has physical characteristics such as high porosity, good water drainage, and aeration, which are fundamental for seed germination (NEVES et al, 2007). The germination performance of desert rose seeds can be

Table 2 - Caudex diameter (CD), seedling length (SL), aerial part shoot length (APL), root length (RL), number of leaves (NL), fresh matter (FM) and dry matter (DM) in desert rose (A. obesum) seedlings on different substrates.

\begin{tabular}{|c|c|c|c|c|c|c|c|}
\hline Treatament & $\mathrm{CD}$ & SL & APL & RL & NL & FM & $\mathrm{DM}$ \\
\hline & \multicolumn{5}{|c|}{------------------------------------- mm ------------------------------------- } & \multicolumn{2}{|c|}{---------------------- g-------------------- } \\
\hline S1 - Soil & $8.7 \mathrm{e}^{1}$ & $72.6 \mathrm{~d}$ & $32.2 \mathrm{c}$ & $40.4 \mathrm{c}$ & $10.5 \mathrm{~b}$ & $1.7 \mathrm{c}$ & $0.07 \mathrm{~d}$ \\
\hline S2 - Sand & $12.7 \mathrm{a}$ & $86.3 \mathrm{c}$ & $26.1 \mathrm{~d}$ & $60.4 \mathrm{~b}$ & $10.3 \mathrm{~b}$ & $0.9 \mathrm{~d}$ & $0.05 \mathrm{e}$ \\
\hline S3 - Carolina & $10.4 \mathrm{c}$ & $105.2 \mathrm{a}$ & $37.9 \mathrm{~b}$ & $67.3 \mathrm{a}$ & $11.9 \mathrm{a}$ & $2.7 \mathrm{a}$ & $0.11 \mathrm{~b}$ \\
\hline S4 - Soil + Carolina & $10.9 \mathrm{~b}$ & $98.7 \mathrm{~b}$ & $42.1 \mathrm{a}$ & $56.6 \mathrm{~b}$ & $10.8 \mathrm{~b}$ & $2.9 \mathrm{a}$ & $0.13 \mathrm{a}$ \\
\hline S5 - Sand + Carolina & $9.3 \mathrm{~d}$ & $94.9 \mathrm{~b}$ & $39.3 \mathrm{~b}$ & $55.6 \mathrm{~b}$ & $11.8 \mathrm{a}$ & $2.2 \mathrm{~b}$ & $0.09 \mathrm{c}$ \\
\hline CV $(\%)$ & 6.1 & 9.5 & 11.1 & 13.4 & 10.9 & 16.9 & 17.9 \\
\hline
\end{tabular}

${ }^{1}$ Means followed by the same letters do not differ from each other by the Scott-Knot test $(p<0.05)$. 


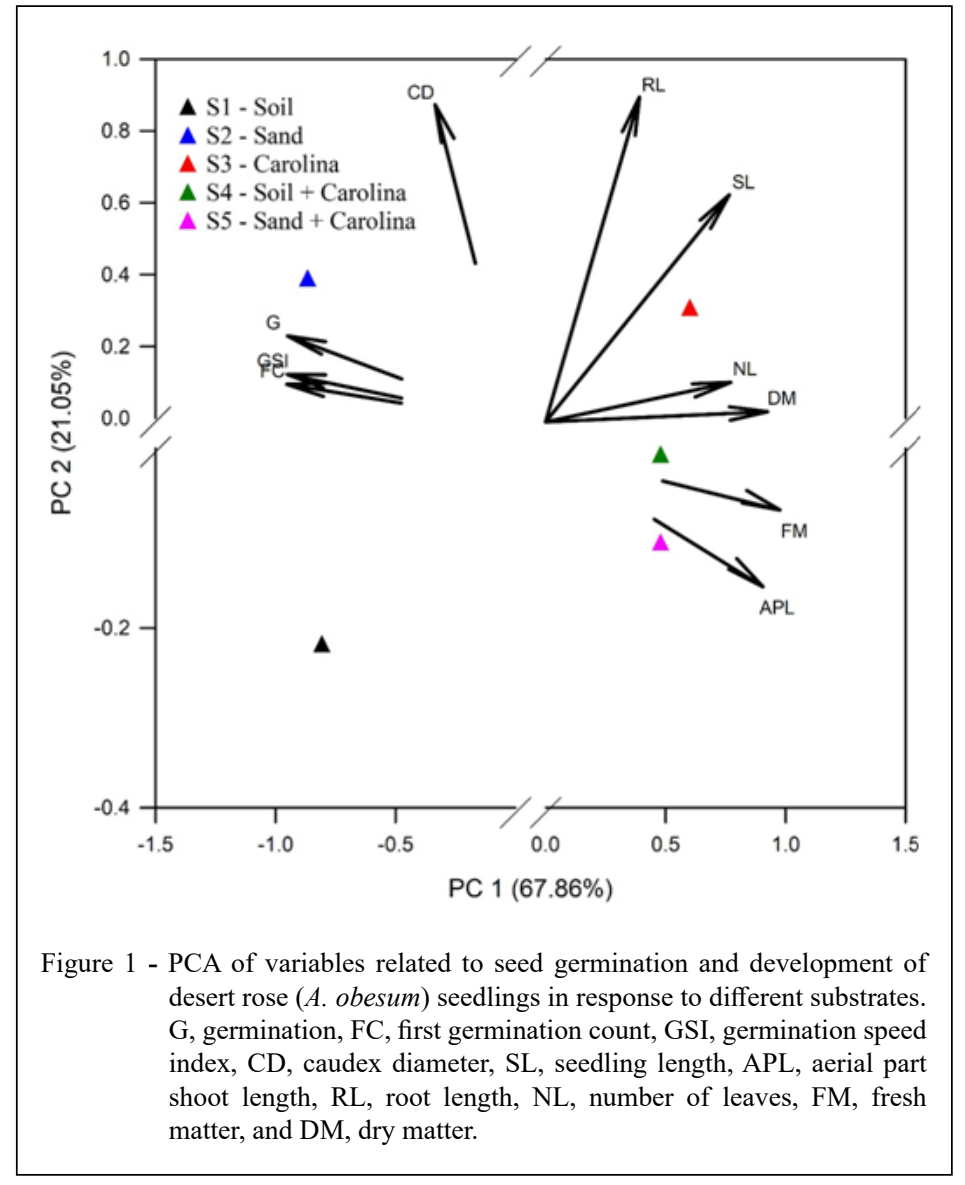

attributed to the adaptation and occurrence of species in sites with sandy soils (HOSSAIN, 2018). However, supplementation with mineral or organic fertilization during plant growth is necessary because sand is low in nutrients (MONFORT, 2015). Sand as a substrate has achieved significant results for seeds of Blepharocalyx salicifolius (Kunth) O.Berg, in which germination was $>90 \%$ (REGO et al., 2009). Moreover, it provided higher germination values and was recommended for forming catingueira seedlings (Caesalpinia pyramidalis (Tul.) E. Gagnon \& G. P. Lewis) (LIMA et al., 2011), silk flower (Calotropis procera (Aiton) W. T. Aiton.) (OLIVEIRA-BENTO et al., 2015), Adenanthera pavonina L. (SOUZA et al., 2007) and Tabebuia aurea Benth. Hook. f ex S. Moore (PACHECO et al., 2008). When using sand as a substrate, higher GSI values were obtained during the formation of jambu seedlings (Spilanthes oleracea L.) (HONÓRIO et al., 2011), and FC and GSI for Moringa oleifera Lam. (NEVES et al., 2007). Sand is also recommended for seed analysis for issuing official bulletins (BRASIL, 2009).
In the initial development of desert rose seedlings, high CD values were obtained in substrates with sand in their composition (COLOMBO et al., 2017). Thus, the abovementioned physical characteristics positively influenced the greater thickening of the stem, an attribute appreciated by consumers of this ornamental plant (STEGANI et al., 2019). Variations in root growth in the different substrates were attributed to their particle size conditions, which may or may not enable rooting, depending on the aeration conditions. Number of leaves, fresh mass, and dry mass variables are suitable for evaluating vigor based on seedling development, and are used to complement the information obtained from germination test (BARBOSA et al., 2012; SILVA et al., 2017). A higher number of leaves is related to more vigorous seedlings because of greater germination potential; and consequently, higher speed of leaf formation. This effect tends to disappear as the plant develops because vigor has a greater influence on the initial performance of seedlings (MONDO et al., 2012). 
Table 3 - Pearson correlation coefficients between the main component scores for the germination variables and development of desert rose (A. obesum) seedlings.

\begin{tabular}{lcc}
\hline Variable & PC 1 & PC 2 \\
\hline Germination & -0.95 & 0.23 \\
First germination count & -0.95 & 0.10 \\
\hline Germination speed index & -0.95 & 0.13 \\
Caudex diameter & -0.33 & 0.88 \\
Seedling length & 0.76 & 0.63 \\
Aerial part shoot length & 0.90 & -0.15 \\
Root length & 0.39 & 0.90 \\
Number of leaves & 0.77 & 0.11 \\
Fresh matter & 0.97 & -0.06 \\
Dry matter & 0.92 & 0.02 \\
\hline
\end{tabular}

The relationships between the variables germination and development of desert rose seedlings and the different substrates can be better explored by the PCA. Results were consistent with the criterion that at least $70 \%$ of the total variability of the original data should be explained in the PCA (SNEATH \& SOKAL, 1973). Treatments were separated into three response groups. Treatment S1 (soil) was not related to the study variables. Treatment S2 (sand) was related to the germinative performance variables of desert rose seeds. Substrates S3 (Carolina), S4 (Soil + Carolina), and S5 (Sand + Carolina) were more closely related to variables associated with biomass input and consequently better development of the vegetative structures of the seedlings. The adequacy of PCA can be seen in other similar researches with satisfactory results (BARBOSA et al., 2013; AULER et al., 2015). Thus, it has been successfully used to evaluate the production of lettuce seedlings in different substrates; moreover, it is possible to analyze the contribution of variables on the seedlings produced, thus generating better combined use of the information (AULER et al., 2015). PCA provided information on the suitability of the substrate for seedling formation of Colubrina glandulosa Perkins (CAMARA et al., 2017).

The use of the isolated commercial substrate or its mixture with soil or sand (1:1) were the treatments that best contributed to developing desert rose seedlings. These treatments provided better conditions of aeration, nutrition, and support for the seedlings because of good compositional balance they offer. Sand; however, was the treatment that least favored the development of the seedlings, indicating that this is not the most suitable substrate for growth and formation of $A$. obesum seedlings.

\section{CONCLUSION}

Sand substrate was best suited for germinating desert rose seeds; however, for forming the seedlings, a mixture of Carolina Soil commercial substrate with sand or soil should be used.

\section{ACKNOWLEDGEMENTS}

This study was financed in part by the Coordenação de Aperfeiçoamento de Pessoal de Nível Superior - Brasil (CAPES) - Finance Code 001.

\section{DECLARATION \\ OF CONFLICT OF INTERESTS}

The authors declare no conflict of interest. The founding sponsors had no role in the design of the study; in the collection, analyses, or interpretation of data; in the writing of the manuscript, and in the decision to publish the results.

\section{AUTHORS' CONTRIBUTIONS}

All authors contributed equally for the conception and writing of the manuscript. All authors critically revised the manuscript and approved of the final version.

\section{REFERENCES}

AULER, A. C.; et al. Lettuce seedlings development index in different substrates using multivariate analysis. Científica, v.43, n.1, p.50-57, 2015. Available from: <http://cientifica.org.br/index. php/cientifica/article/view/604/372>. Accessed: Jun. 12, 2019. doi: 10.15361/1984-5529.2015v43n1p50-57.

BARBOSA, R. M.; et al. Electrical conductivity and water content in peanut seeds. Ciência Rural, v.42, n.1, p.45-51, 2012. Available from $<$ http://www.scielo.br/scielo.php?script=sci_arttext\&pid=S010384782012000100008\&lng=en\&nrm=iso>. Accessed: Aug. 19, 2019. doi: 10.1590/S0103-84782012000100008. 
BARBOSA, R. M.; et al. Discrimination of soybean seed lots by multivariate exploratory techniques. Journal of Seed Science, v. 35 , n.3, p.302-310, 2013. Available from <http://www.scielo.br/scielo. php?script $=$ sci arttext\&pid $=$ S2317-15372013000300005\&lng $=$ en\&nrm=iso $>$. Accessed: Jun. 05, 2019. doi: 10.1590/S2317. 15372013000300005 .

BRASIL. Ministério de Agricultura, Pecuária e Abastecimento. Regras para análise de sementes. 399p. 2009.

CAMARA, R.; et al. Effects of substrate and mycorrhizal inoculation on the production of seedlings of Colubrina glandulosa Perkins. Floresta, v.47, n.4, p.449-458, 2017. Available from: $<$ https://revistas.ufpr.br/floresta/article/view/50661/34365>. Accessed: Jun. 05, 2019. doi: 10.5380/rf.v47i4.50661.

COLOMBO R. C.; et al. Production of desert rose seedlings in different potting media. Ornamental Horticulture, v.23, n.3, p.250-256, 2017. Available from: <https://ornamentalhorticulture. emnuvens.com.br/rbho/article/view/1039/729>. Accessed: Aug. 07, 2019. doi: 10.14295/oh.v23i3.1039.

COLOMBO, R. C.; et al. Biometric description of fruits and seeds, germination and imbibition pattern of desert rose [Adenium obesum (Forssk.), Roem. \& Schult]. Journal of Seed Science, v.37, n.4, p.206-213, 2015. Available from: <http://www.scielo.br/scielo. php?script=sci_arttext\&pid=S2317-15372015000400206\&lng $=$ en\&nrm $=$ iso $>$. Accessed: Jun. 22, 2019. doi: 10.1590/2317$1545 \mathrm{v} 37 \mathrm{n} 4152811$.

GOMES-JUNIOR, G. A.; et al. Substrate and quality mangosteen seedlings. Revista Brasileira de Fruticultura, v.41, n.3, e-135, 2019. Available from: <http://www.scielo.br/scielo. php?script=sci_arttext\&pid=S0100-29452019000301004\&lng $=$ pt\&nrm=iso $>$. Accessed: Aug. 19, 2019. doi: 10.1590/010029452019135.

HASTUTI, D.; et al. Variation of morphology, karyotype and protein band pattern of adenium (Adenium obesum) varieties. Nusantara Bioscience, v.1, n.2, p.78-83, 2009. Available from: $<$ https://www.smujo.id/nb/article/view/992>. Accessed: Jun. 14, 2019. doi: $10.13057 /$ nusbiosci/n010205.

HONÓRIO, I. C. G.; et al. Influence of diferente substrates on the germination of jambu (Spilanthes oleracea L. - Asteraceae). Biotemas, v.24, n.2, p.21-25, 2011. Available from: <https:// periodicos.ufsc.br/index.php/biotemas/article/viewFile/21757925.2011v24n2p21/17816>. Accessed: Jun. 12, 2019. doi: $10.5007 / 2175-7925.2011 \mathrm{v} 24 \mathrm{n} 2 \mathrm{p} 21$.

HOSSAIN, A. A review on Adenium obesum: A potential endemic medicinal plant in Oman. Beni-Suef University Journal of Basic and Applied Sciences. v.7, n.1, p.559-563, 2018. Available from: $<$ https:// www.sciencedirect.com/science/article/pii/S2314853518302385>. Accessed: Jun. 11, 2019. doi: 10.1016/j.bjbas.2018.06.008.

LIMA C. R.; et al. Temperature and substrate effects on the germination of Caesalpinia pyramidalis Tul. seeds. Revista Brasileira de Sementes, v.33, n.2, p.216-222, 2011. Available from: $<$ http://www.scielo.br/scielo.php?script=sci_arttext\&pid=S010131222011000200003\&lng=en\&nrm=iso $>$. Accessed: Jun. 09, 2019. doi: 10.1590/S0101-31222011000200003.

MAGUIRE, J. D. Speed of germination aid in selection and evaluation for seedling emergence and vigor. Crop Science, v.2, n.2, p.76-77, 1962.
MONDO, V. H. V.; et al. Maize seed vigor and plant performance. Revista Brasileira de Sementes, v.34, n.1, p.143-155, 2012. Available from: $\quad<\mathrm{http} / /$ www.scielo.br/scielo.php?script=sci_ arttext\&pid $=$ S0101-31222012000100018\&lng $=$ en\&nrm $=$ iso $>$. Accessed: Jun. 13, 2019. doi: 10.1590/S0101-31222012000100018.

MONFORT, L. E. F.; et al. Micropropagation and in vitro seed germination of atroveran. Revista Ceres, v.62, n.2, p.215223, 2015. Available from: <http://www.scielo.br/scielo. php?script=sci_arttext\&pid=S0034-737X2015000200215\&lng $=$ en\&nrm=iso $>$. Accessed: Aug. 28, 2019. doi: 10.1590/0034737X201562020012.

NEVES, N. A.; et al. Germination of seeds and seedling growth of Moringa oleifera Lam. Revista Caatinga, v.20, n.2, p.63-67, 2007. Available from: $<$ https://periodicos.ufersa.edu.br/index.php/ caatinga/article/view/319/114>. Accessed: Aug. 09, 2019.

OLIVEIRA-BENTO, S. I.; et al. Storage of silk flower [Calotropis procera (Aiton) W.T. Aiton]. Revista Caatinga, v.28, n.1, p.39-47, 2015. Available from: <https://periodicos. ufersa.edu.br/index.php/caatinga/article/view/3831/pdf 214>. Accessed: Aug. 01, 2019.

PACHECO, M. V.; et al. Seed germination and initial growth of Tabebuia aurea (Silva Manso) Benth. \& Hook F. ex S. Moore. Ciência Florestal, v.18, n.2, p.143-150, 2008. Available from: $<$ http://www.scielo.br/scielo.php?script=sci_arttext\&pid=S198050982008000200143\&lng $=$ en\&nrm=iso $>$. Accessed: Jun. 24, 2019. doi: $10.5902 / 19805098452$.

REGO, S. S.; et al. Germination of seeds of Blepharocalyx salicifolius (H.B.K) Berg. in different substrates and conditions of temperatures, light and moisture. Journal of Seed Science, v.31, n.2, p.212-220, 2009. Available from: <http://www.scielo.br/scielo. php?script $=$ sci_arttext\&pid $=$ S0101-31222009000200025\&lng $=$ en\&nrm=iso $>$. Accessed: Jun. 14, 2019. doi: 10.1590/S010131222009000200025.

ROMAHN, V. Enciclopédia ilustrada das plantas \& flores: suculentas, samambaias e aquáticas. São Paulo: Editora Europa, 2012.

SILVA, C. B.; et al. Accelerated aging as vigor test for sunn hemp seeds. Ciência Rural, v.47, n.1, e20151527, 2017. Available from: $<$ http://www.scielo.br/scielo.php?script=sci arttext\&pid=S010384782017000100402\&lng=pt\&nrm=iso $>$. Accessed: Aug. 19, 2019. doi: $10.1590 / 0103-8478 \mathrm{cr} 20151527$.

SNEATH, P. H.; SOKAL, R. R. Numerical taxonomy: the principles and practice of numerical classification. San Francisco: W. H. Freeman, 1973. 573p.

SODRÉ, G. A.; GOMES, A. R. S. Cocoa propagation, technologies for production of seedlings. Revista Brasileira de Fruticultura, v.41,n.2, e-782, 2019. Available from: $<$ http://www.scielo.br/scielo. php? script $=$ sci_arttext\&pid=S0100-29452019000201003\&lng $=$ pt\&nrm=iso $>$. Accessed: Aug. 19, 2019. doi: 10.1590/010029452019782.

SOUZA, E. B.; et al. Germination of Adenanthera pavonina $L$. seeds as a function of different temperatures and substrates. Revista Árvore, v.31, n.3, p.437-443, 2007. Available from: $<$ http://www.scielo.br/scielo.php?script=sci_arttext\&pid=S010067622007000300009\&lng=en\&nrm=iso $>$. Accessed: Jun. 03, 2019. doi: $10.1590 / \mathrm{S} 0100-67622007000300009$. 
STEGANI, V.; et al. Growth of fertigated desert rose in different nitrate/ammonium proportion. Ornamental Horticulture, v.25, n.1, p.18-25, 2019. Available from: <http://www.scielo.br/ scielo.php?script $=$ sci_arttext\&pid=S2447-536X201900010001 8\&lng=en\&nrm=iso>. Accessed: Aug. 07, 2019. doi: 10.14295/ oh.v25i1.1248
TALUKDAR, T. Development of NaCl-tolerant line in an endangered ornamental, Adenium multiflorum Klotzsch through in vitro selection. International Journal of Recent Scientific Research, v.3, n.10, p.812-821, 2012. Available from: <https:// www.recentscientific.com/sites/default/files/Download_310.pdf $>$. Accessed: Aug. 04, 2019. 